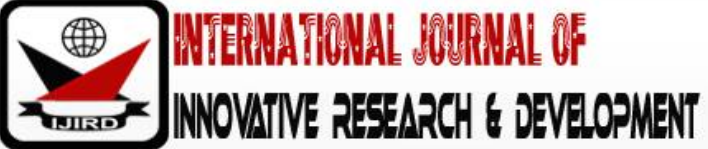

ISSN 2278 - 0211 (Online)

\section{Rapid Assessment of Compositional Stability in Improved Sweet Potato Varieties: Relevance in Breeding and Utilization}

Evelyn Adu-Kwarteng
Senior Research Scientist, Department of Postharvest Section,
Ibok Oduro
Council for Scientific and Industrial Research, Crops Research Institute, Kumasi, Ghana
Professor, Department of Food Science and Technology
Kwame Nkrumah University of Science and Technology, Kumasi, Ghana
William Otoo Ellis
Professor, Department of Food Science and Technology,
Kwame Nkrumah University of Science and Technology, Kumasi, Ghana
Jacob K. Agbenorhevi
Senior Lecturer, Department of Food Science and Technology,
Kwame Nkrumah University of Science and Technology, Kumasi, Ghana

\begin{abstract}
:
Compositional changes that occur in sweet potato after harvest can lead to inconsistencies in processed products. A better understanding of factors influencing these postharvest changes is necessary to enhance marketing, processing and utilization. This study applied a rapid and ecologically-friendly approach in investigating the influence of maturity and short-term storage on the stability of starch, protein and soluble sugar contents in six improved sweet potato varieties. Fresh roots harvested at 3.5, 4 and 5 months after planting were prepared into flour at harvest time and also after three weeks' storage under tropical ambient conditions. Composition was studied using Near Infra-red Reflectance Spectroscopy (NIRS) as a chemical-free, non-polluting, cost effective and rapid method of analysis. At harvest time protein contents ranged from 3.0\% to $7.25 \%$, starch contents $53.93 \%$ to $79.40 \%$ and total soluble sugars $3.92 \%$ to $25.02 \%$. Protein content was significantly influenced by harvest maturity $(p<0.001)$, but not by storage; it was generally higher at 3.5 months and reduced with increasing maturity. For starch and total soluble sugar contents the influence of maturity was significant ( $p<0.01$ and $p<0.001$ respectively); the influence of storage was also significant ( $p<0.001$ and $p<0.05$ respectively). In all the varieties, there were reductions in starch content during storage ranging from $1.95 \%$ $23-73 \%$ of the total starch. Varieties with lower original starch contents were more susceptible to starch loss during storage. Soluble sugar contents increased concomitantly with the loss of starch during storage. This rapid assessment is useful in the efforts to maintain a fair level of quality control in harvested produce through appropriate varietal selection and harvest timing, and to target suitable uses for different sweet potato varieties.
\end{abstract}

Keywords: Varietal selection, harvest maturity, Near infra-red reflectance spectroscopy

\section{Introduction}

Sweet potato (Ipomoea batatas L.) is a versatile and nutritious root crop cultivated in more than 100 countries. It is gaining increased significance globally not only as a health food and a staple food for domestic consumption but also as a raw material base in commercial processing (Truong \& Avula 2010). The crop is very productive and has the potential to play key roles in food and nutritional security. It is known to be genetically diverse and nutritionally superior to most wellknown starchy staples, containing vitamins, minerals, soluble fiber and other bio-active compounds (Kays 2005a); it also has a low glycemic index (WHFoods 2011; Allen et al., 2012) in spite of this it has experienced persistent low utilization for decades (Kays 2005b; Shih et al., 2009). Sweet potato has been described as one of the most misunderstood of the major food crops (Scott \& Maldonado 1998). Due to its wide genetic diversity coupled with inherent postharvest changes that occur (Zhang et al., 2002), it is often difficult to determine the most suitable characteristics for particular products and what accounts for inconsistencies in product characteristics when using any particular variety. Although changes occurring during storage may be inevitable, a better understanding of factors influencing these postharvest changes is necessary if marketing and utilization are to be enhanced in a sustainable manner. In many tropical regions, in spite of the warm climate, there are no well-established systems for efficient long-term storage of sweet potato fresh roots; this is in contrast to some developed economies where storage for several months up to even a year is possible through the use of sophisticated facilities. A study on several cultivars in East Africa (Rees et al., 2003) reported that in tropical developing countries under marketing conditions, sweet potato has a shelf-life of only 1-2 weeks. In Ghana storage for a month or 
more under improved conditions have been achieved (Teye 2010). There is insufficient information on the factors that can influence various important quality attributes of sweet potato during storage, and how to control or manipulate these quality characteristics. Unlike most other crops, sweet potato storage roots do not have any clear maturity stage. Rather the roots grow indefinitely, and under favorable conditions will continue to enlarge until the interior of the root becomes anaerobic or rots. Due to this characteristic, the crop is harvested when majority of the storage roots have reached the desired size (Kays 1998); this method of determining when to harvest is quite subjective and remains at the discretion of the farmer. In the quest to find means of understanding how to achieve and maintain optimal quality characteristics in sweet potato, various workers have investigated the influence of cultivation conditions on sweet potato starch properties (Noda et al., 2001; Genkina et al., 2003; Ishiguro et al., 2003). Harvest time, being easy to manipulate in the crop's production cycle, may offer some amount of control if it is found to significantly influence fresh roots components that can impact processing and eating quality. In Ghana, several improved varieties with diverse characteristics have been developed and released. The aim of this study was to identify the influence of maturity on major components of some improved varieties, and the impact on their stability during storage of harvested roots under tropical ambient conditions. Near Infra-red Reflectance Spectroscopy (NIRS) was used in sample analysis, as a chemical-free, non-polluting, cost effective and rapid method of analysis. The relevance of NIRS in this study is its rapidity and also the lower carbon print that makes such research more environmentally sustainable.

\section{Materials and Methods}

\subsection{Sample Preparation}

Six (6) improved high-yielding and disease-resistant varieties of sweet potato obtained from CSIR-Crops Research Institute, Ghana were cultivated at Fumesua in the Ashanti Region under identical management practices and harvested at 3.5, 4 and 5 months after planting. At each harvest time, a batch of representative was processed immediately into flour while the other batch was stored at room temperature $\left(25^{\circ} \mathrm{C} \pm 4\right)$ for 3 weeks before being processed into flour. In the preparation of flour, fresh roots were washed and air-dried, peeled, sliced with a mandolin and freeze-dried for 72 hours before milling (using a Cyclotec 1093 sample mill) to pass through a 60-80 mesh screen. Flour samples were kept in airtight sample bags at room temperature until the time of analysis.

\subsection{Compositional Analysis}

Near Infra-red Reflectance Spectroscopy (NIRS, Model XDS Near infra-red; XM-1100 series, Sweden) was used to analyze nutrient components in freeze-dried sweet potato flour samples. The pre-set calibrations used were developed by the International Potato Center (CIP), Peru. Each sample was spread into a special NIRS cuvette and scanned using calibrations for protein, starch and soluble sugars (sucrose, glucose and fructose). All tests were run in triplicate.

\subsection{Statistical Analysis}

Experimental design was a Split-split-plot design as follows:

Main plot: $\quad$ Variety (6 varieties)

Sub-plot: $\quad$ Storage (2 levels)

Sub-sub-plot: Maturity (3 levels)

Statistical analysis was done using GenStat Release 12.1 (2009).

\section{Results and Discussion}

\subsection{Protein Content}

Protein contents ranged from $3.0 \%$ to $7.25 \%$ and the influence of maturity was found to be highly significant $(\mathrm{p}<0.001$, Table 1). Protein content was generally higher at earlier maturity (3.5 months) and reduced with increasing maturity (Fig. 1). Therefore, for child feeding programs or other purposes where protein content needs to be maximized, sweet potato harvested at early maturity may be recommended.

\begin{tabular}{|c|c|c|c|c|}
\hline Source Of Variation & D.F. & STARCH (\%) & PROTEIN (\%) & TOTAL SOLUBLE SUGARS (\%) \\
\hline VARIETY & 5 & $1237.89 * * *$ & $6.12^{* * *}$ & $804.2^{* * *}$ \\
\hline Residual & 10 & 3.65 & 0.13 & 8.1 \\
\hline STORAGE & 1 & $1237.23^{* * *}$ & $0.26 \mathrm{~ns}$ & $1120.8^{* * *}$ \\
\hline VARIETY x STORAGE & 5 & $22.65^{* * *}$ & $3.72^{* * *}$ & $39.1^{*}$ \\
\hline MATURITY & 2 & $13.54^{* *}$ & $46.91^{* * *}$ & $105.7^{* * *}$ \\
\hline VARIETY x MATURITY & 10 & $26.74^{* * *}$ & $3.28^{* * *}$ & $31.4^{* *}$ \\
\hline STORAGE $\times$ MATURITY & 2 & $4.68 \mathrm{~ns}$ & $2.67^{* * *}$ & $40.7^{*}$ \\
\hline VARIETY $x$ STORAGE $x$ & \multirow[t]{2}{*}{10} & \multirow[t]{2}{*}{$14.26^{* * *}$} & \multirow[t]{2}{*}{$1.39^{* * *}$} & \multirow[t]{2}{*}{$27.5^{* *}$} \\
\hline MATURITY & & & & \\
\hline Residual & 42 & 2.28 & 0.13 & 9.1 \\
\hline
\end{tabular}

Table 1: Influence of Variety, Storage and Maturity on Major Components of Improved Sweet Potato Varieties

(Mean Squares from Combined Analysis of Variance)

***Significant at $P<0.001 ;{ }^{* *}$ Significant at $P<0.01$; *Significant at $P<0.05$ 
The influence of storage was however not significant (Table 1). Protein content of sweet potato is reported to range from 1.3 to $>10 \%$ (dry matter basis); however, there is evidence of considerable variability varieties and also even within the same variety due to the influence of genetic factors, production practices and environmental conditions (Collins \& Walter 1985).Although non-protein Nitrogen (NPN) forms part of sweet potato's total Nitrogen content, the nutritional quality of sweet potato protein is reported to be high. Some studies (Walter \& Catignani 1981; Walter et al., 1983) reported that the protein efficiency ratio (PER) of isolates and concentrates was nearly equal to that of casein, and depended on the severity of the heat treatment used in the manufacture of the sweet potato flour.

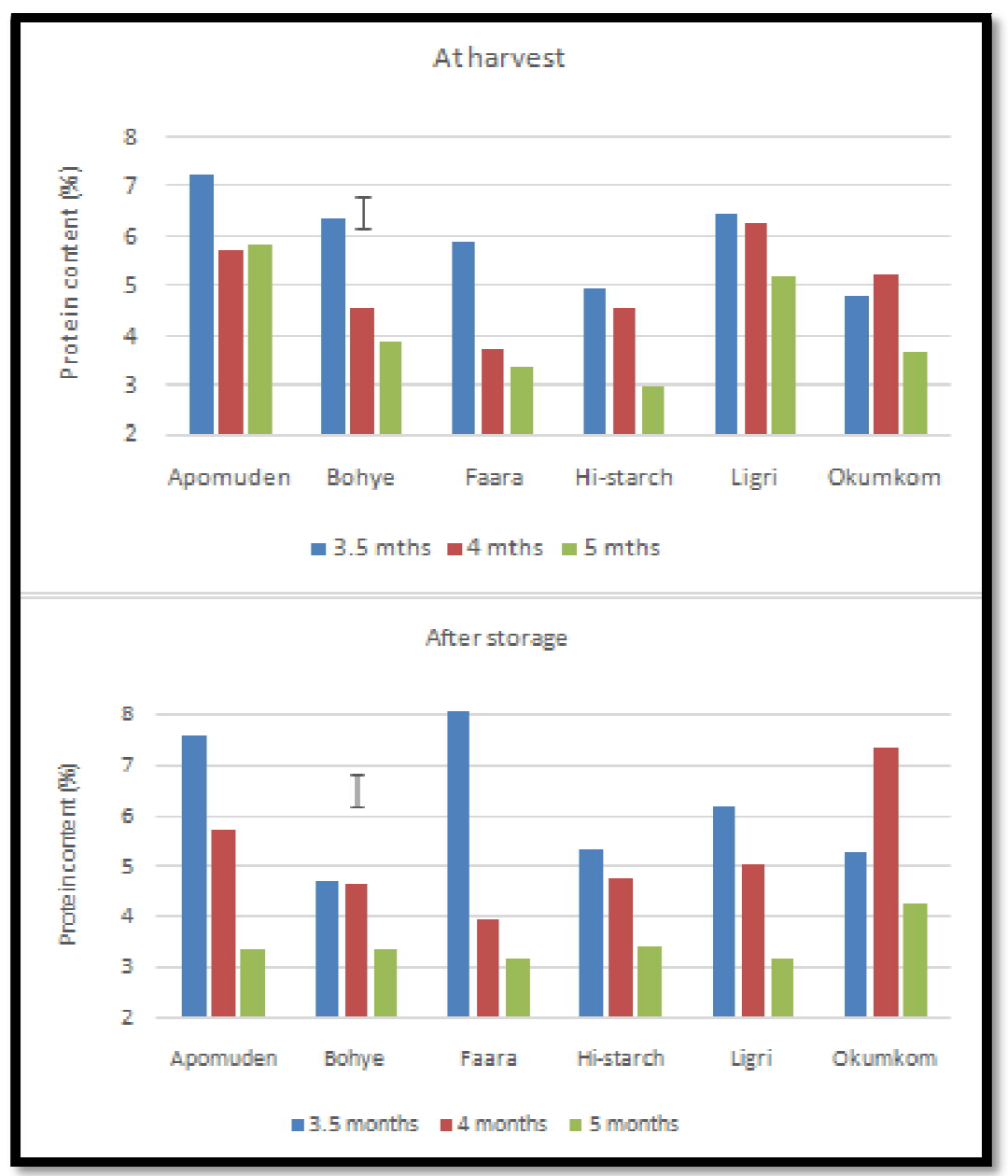

Figure 1: Protein Contents (\% Dwb) of Sweet Potato Varieties at Harvest Time and after Storage, (Error Bar Shows LSD (0.614) For Effect of Variety X Maturity X Storage Interaction; LSD for the Effects of Maturity and Storage Were 0.174 and 0.164 Respectively. $P<0.001$ )

Decreases in protein content during storage (shown as negative values) (Table 2) were observed at various points in all varieties with the exception of Hi-starch; overall, the extent of decrease was highest at 5 months.

\begin{tabular}{|c|c|c|c|}
\hline & 3.5 months & 4 months & 5 months \\
\hline Apomuden & +4.69 & -1.22 & -42.91 \\
\hline Bohye & -23.55 & +1.75 & -13.59 \\
\hline Faara & +34.86 & +5.07 & -7.08 \\
\hline Hi-starch & +7.04 & +4.18 & +13.67 \\
\hline Ligri & -4.32 & +16.35 & -39.42 \\
\hline Okumkom & +11.43 & -4.56 & +15.14 \\
\hline OVERALL (NET) & +30.15 & +21.56 & -74.19 \\
\hline Table 2: Percentage (\%) Changes in Protein Content after Storage of Sweet \\
Potato Varieties, Harvested at Different Levels of Maturity, Indicating \\
Relative Stability during Storage
\end{tabular}

These decreases could be due to various metabolic processes that take place in living tissues of the fresh roots. Interestingly, increases in protein content after storage were found to occur for each variety in at least one maturity stage or more (Table 2). This strange phenomenon could be due to what has been described as 'de novo synthesis' of proteins e.g. enzymes such as sucrose synthase, starch phosphorylase, amylases, etc. (Hagenimana et al., 1994), reported to occur in 
sweet potato especially when stored roots break dormancy in response to various signals, in preparation to begin sprouting. Further studies may be necessary to throw more light on this phenomenon.

\subsection{Starch Content}

At harvest time starch contents ranged from $53.93 \%$ to $79.40 \%$ and after storage reduced to $41.13 \%-75.16 \%$ (dry basis) (Table 3).

\begin{tabular}{|c|c|c|c|}
\hline At Harvest & 3.5 mths & 4 mths & 5 mths \\
\hline Apomuden & 58.58 & 56.14 & 53.93 \\
\hline Bohye & 67.59 & 68.95 & 68.49 \\
\hline Faara & 73.37 & 73.58 & 71.48 \\
\hline Hi-starch & 78.81 & 78.41 & 79.4 \\
\hline Ligri & 64.25 & 71.81 & 71.06 \\
\hline Okumkom & 68.7 & 65.81 & 66.02 \\
\hline AFTER STORAGE & 3.5 mths & 4 mths & 41.13 \\
\hline Apomuden & 47.89 & 46.6 & 63.22 \\
\hline Bohye & 59.13 & 59.23 & 70.08 \\
\hline Faara & 63.51 & 69.55 & 75.16 \\
\hline Hi-starch & 71.93 & 71.49 & 63.07 \\
\hline Ligri & 61.69 & 64.81 & 61.12 \\
\hline Okumkom & 59.61 & 62.98 & \\
\hline
\end{tabular}

Table 3: Starch Contents (\%, Dry Basis) of Sweet Potato Varieties at Different Maturity Stages, at Harvest and after Storage

Starch content has significant impact on the eating quality of sweetpotato varieties, and a wide range is reported in literature (Brabet et al., 1998; Truong \& Avula 2010). The influence of maturity on starch content was found to be significant at $\mathrm{p}<0.01$ while that of storage was significant at $\mathrm{p}<0.001$. The interaction between maturity and storage was however not statistically significant; varietal differences were however, highly significant $(\mathrm{p}<0.001)(\mathrm{Table} 1)$. In all the varieties, there were losses of starch content during storage, ranging from 1.95\% - 23-73\% of the total starch. Apomuden (with the lowest original starch content) had the highest reduction in starch content with storage; Faara and Hi-starch (with the highest original starch contents) had the lowest reduction or degradation of starch during storage, with Histarch showing the best stability in starch content across maturity stages (Fig. 2).

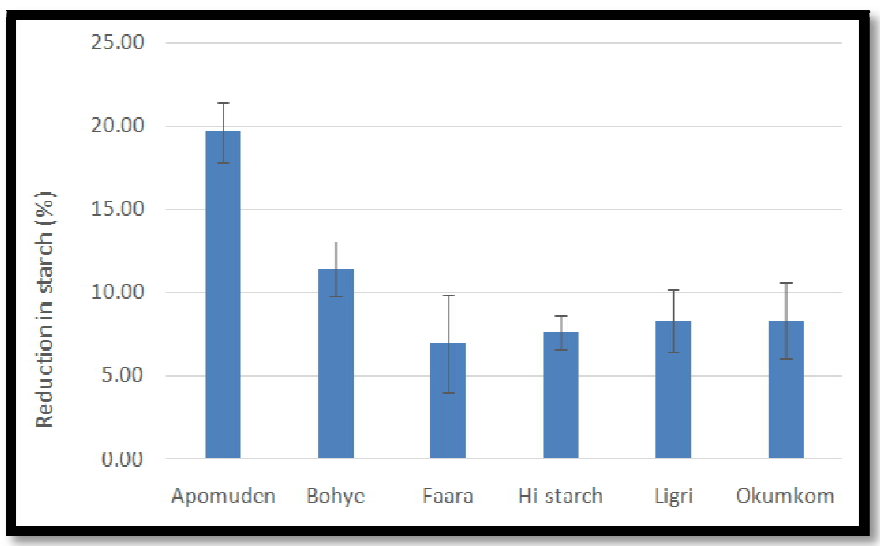

Figure 2: Average Reduction in Starch Content (\% of Original Starch) after Storage of Sweet Potato Varieties (Error Bars Are Standard Deviations for Three (3) Levels of Maturity)

The extent of reduction or degradation of starch during storage correlated negatively $(\mathrm{r}=-0.61)$ with initial starch content (Table 4), indicating higher stability or higher resistance to starch degradation in varieties containing more starch.

\begin{tabular}{|c|c|c|}
\hline \multicolumn{3}{|c|}{$\begin{array}{c}\text { Correlation Coefficient (r) } \\
\text { Starch content }\end{array}$} \\
\hline 3.5 months & -0.32 & 0.04 \\
\hline 4 months & -0.55 & 0.26 \\
\hline 5 months & -0.83 & 0.91 \\
\hline OVERALL & -0.61 & 0.52 \\
\hline
\end{tabular}

Table 4: Correlations between Starch Losses (\%) during Storage and Original

Starch or Protein Contents (\% Dwb) (Six Sweet Potato Varieties Harvested Across Three Maturity Stages)

This association between original starch content and the stability of starch during storage was found to be greater at advanced maturity, the highest correlation being observed at 5 months $(r=-0.83)$ (Table 4). Various enzymes are 
known to be involved in starch metabolism of sweet potato even during the postharvest phase; these include alphaamylase and starch phosphorylase, among others. Since enzyme proteins are reported to form a substantial proportion of the fresh root tuber proteins, links between protein content and postharvest starch degradation was investigated; a high correlation $(r=0.91)$ was observed in samples harvested at 5 months (Table 4). This means that at 5 months, high protein content was linked with high postharvest loss of starch, while low protein content was linked with better stability of starch during storage. Further study is however required to understand the association between protein content and postharvest starch stability, and especially the influence of harvest maturity on this phenomenon. Starch content in sweet potato correlates well with dry weight (Li and Liao, 1983); in some parts of the world as dry weight increases, there is said to be a corresponding decrease in acceptability as a table food (Lin et al., 1995). However, high dry matter content is generally desirable in many African sweet potato-based products (Ellis et al., 2001; Adu-Kwarteng et al., 2003; CSIR-CRI 2012), and levels above $35.0 \%$ are also desirable for raw materials in the starch processing industry (Mok et al., 1997).

\subsection{Soluble Sugar Contents}

Total soluble sugars (TSS) ranged from $3.92 \%$ to $44.44 \%$. The lowest was in Hi-starch at 3.5 months at harvest and the highest was in Apomuden at 5 months after storage (Fig. 3).

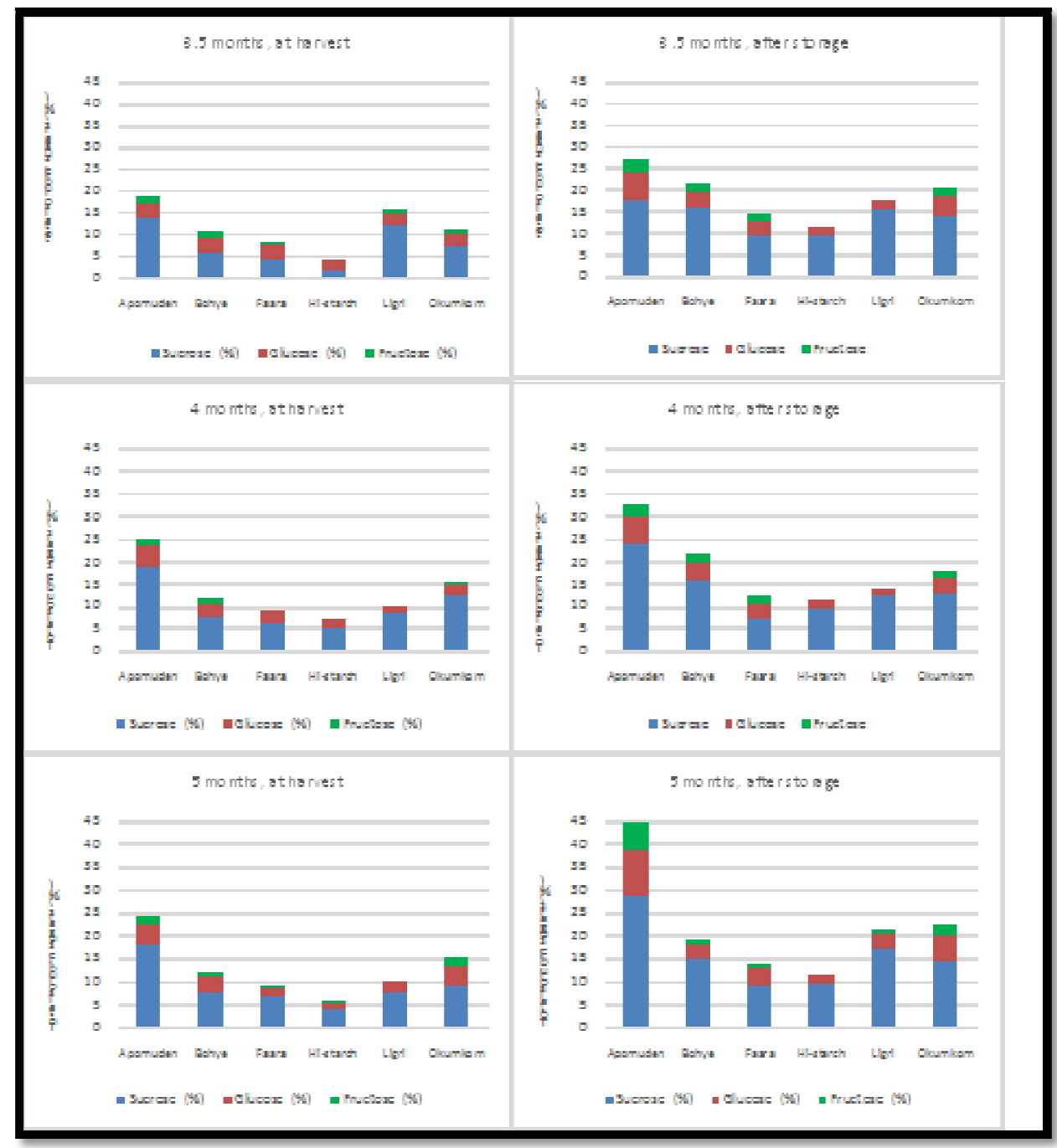

Figure 3: Soluble Sugars (\% Dwb) in Sweet Potato Varieties at 3.5, 4and 5-Months Maturity, Before and after Storage

The influence of maturity and storage were both significant at $\mathrm{p}<0.001$ and the interaction between maturity and storage was also significant at $\mathrm{p}<0.05$ (Table 1). Sugar in sweet potato is a key component of its flavor and eating quality (Kays 2005a). In Ghana many communities indicated the desire for non-sweet or low-sugar sweet potatoes for adoption as a staple in their diets, as sweet taste is generally associated with luxury food, dessert or snack and not with staple foods (Oduro, 2013; Baafi, 2014; Carey et al., 2019). Information on changes in sugar content that occur during storage should therefore be a vital component in the promotion of sweet potato, especially in the case of high beta-carotene varieties which are employed in combating endemic vitamin A deficiency in deprived communities. The lowest sugar contents were observed at early maturity, especially at 3.5 months when processed after harvest without storage; the influence of storage on the build-up of sugars was highest in samples harvested at 5 months (Fig. 3). The variety 'Bohye' exhibited a unique feature, being a moderate beta-carotene variety (light orange-fleshed colour) and yet having relatively low sugar contents at all maturity stages. Beta-carotene is reported to be genetically linked with high sugar content (Mcharo \& La Bonte 
2007). The influence of maturity and storage history as a focus during the screening of sweet potato genotypes in breeding programs may be one of the keys to unlocking more unique features of this diverse crop. The highest contents for each type of sugar (i.e. sucrose, glucose and fructose) were observed at 5 months after storage (Fig. 3). Significant changes in sugar content during storage have been well-documented (Lewthwaite et al., 1997) although often the changes were reported to be quite random without well-defined trends, even within the same variety (Deobald et al., 1970). This highlights the importance of considering maturity when studying any particular variety for important traits. Results from other studies also highlight the varietal diversity of sweet potato (La Bonte et al., 2000; Nath et al., 2005; Wang et al., 2006; Adu-Kwarteng et al., 2014). The role of other external factors, e.g. time of planting also cannot be overlooked. A wider spectrum of varieties and also the possible influence of planting season on carbohydrate accumulation need to be studied further.

\section{Conclusions}

The influence of maturity on protein, starch and soluble sugar content was significant $(\mathrm{p}<0.001, \mathrm{p}<0.01$ and $\mathrm{p}<0.001$ respectively); varietal differences in these components were also significant $(\mathrm{p}<0.001)$. Short-term storage under ambient conditions was found to influence starch and total soluble sugar contents significantly $(\mathrm{p}<0.001$ and $\mathrm{p}<0.05$ respectively), but not protein content. Increase in sugar content was concomitant with loss or reduction in starch content. The negative association between original starch content and degradation of starch during storage was found to be greater at advanced maturity $(\mathrm{r}=-0.83)$. This means that if a high-starch variety is targeted for the starch industry it would be better to harvest at 5 months to minimize starch losses during storage; more studies are however needed in this regard. Changes in carbohydrate composition are important as they can affect processing and eating quality (texture, viscosity, etc.), or suitability of a harvested crop as a raw material in industry. This rapid and ecologically-friendly method of compositional analysis (using NIRS) is useful in the efforts to maintain a fair level of quality control in harvested produce through appropriate varietal selection and harvest timing, and to target suitable uses for different sweet potato varieties.

\section{Recommendations}

- Since sweet potato is regarded as a 'health food', the influence of maturity on the contents of important biologically active compounds (e.g. soluble fiber, phenolic antioxidants, etc.) in selected varieties should be determined

- $\quad$ Further studies are required to understand the link between protein content and the rate of postharvest starch degradation

\section{Acknowledgement}

The Authors gratefully acknowledge the West Africa Agricultural Productivity Program (WAAPP)-Ghana (under the World Bank) for providing funds for this study. The staff of CIP (International Potato Center) - Ghana are also acknowledged and appreciated very much for their input into NIRS analysis of the samples.

\section{References}

i. Adu-Kwarteng, E., J. A. Otoo, and I. Oduro. 2003. 'Screening of Sweet potato for Poundability into 'fufu'.' In Root Crops: The Small Processor and Development of Local Food Industries for Market Economy. Proceedings of the Eighth Triennial Symposium of the International Society for Tropical Root Crops - Africa Branch (ISTRC-AB), International Institute of Tropical, 138-41.

ii. Adu-Kwarteng, Evelyn, Esther O. Sakyi-Dawson, George S. Ayernor, Van-Den Truong, Fred Shih, and Kim Daigle. 2014. 'Variability of Sugars in Staple-Type Sweet Potato (Ipomoea Batatas) Cultivars: The Effects of Harvest Time and Storage.' Int J Food Properties 17 (2): 410-20. doi:10.1080/10942912.2011.642439.

iii. Allen, Jonathan C, Alexis D Corbitt, Katherine P Maloney, Masood S Butt, and Van-den Truong. 2012. 'Glycemic Index of Sweet Potato as Affected by Cooking Methods.' The Open Nutrition Journal 6: 1-11.

iv. Baafi, E. 2014. 'Development of End-User Preferred Sweet potato Varieties in Ghana.' PhD Thesis. University of Ghana.

v. Brabet, C., D. Reynoso, D Dufour, C. Mestres, J. Arredondo, and G. Scott. 1998. 'Starch Content and Properties of 106 Sweet potato Clones from the World Germplasm Collection Held at CIP, Peru. International Potato Center, Program Report.'

vi. Carey E., Swanckaert J., Dery E., Akansake D., Saaka J., Abidin P., Adofo K., Baafi E., Acheremu K., Adu-Kwarteng E., Muzhingi T., David M., Low J. and Grüneberg W. 2019. Developing and deploying non- and low-sweet sweet potato varieties for expanding markets. September 2019. Acta Horticulturae. DOI: 10.17660/ActaHortic.2019.1251.26

vii. Collins, Wanda W., and W. M. Walter. 1985. 'Fresh Roots for Human Consumption.' In Sweet potato Products: A Natural Resource for the Tropics, edited by John C. Bouwkamp, 153-73. CRC Press, Inc. Boca Raton, Florida.

viii. CSIR-CRI. 2012. 'Sweet potato Genotypes Proposed for Release.' Kumasi, Ghana.

ix. Deobald, H. J., V. C. Hasung, and E. A. Catalano. 1970. 'Variability of Increases in $\alpha$-Amylase and Sugars during Storage of Goldrush and Centennial Sweet potatoes.' Journal of Food Science 36 (3): 413-15.

X. Ellis, W. O., I. Oduro, K. Fianko, and J. A. Otoo. 2001. 'Quality of Gari from Eighteen (18) Sweet potato Varieties.' In 8th Triennial Conference of ISTRC-AB, IITA, Ibadan, Nigeria, 12-16th November 2001.

xi. Genkina, Natalia K., Takahiro Noda, Galina I. Koltisheva, Luybov A Wasserman, Richard F Tester, and Vladimir P Yuryev. 2003. 'Effects of Growth Temperature on Some Structural Properties of Crystalline Lamellae in Starches Extracted from Sweet Potatoes (Sunnyred andAyamurasaki).' Starch - Stärke 55 (8): 350-57. 
doi:10.1002/star.200300145.

xii. Hagenimana, Vital, Ronald E Simard, and Louis-P. Vézina. 1994. 'Amylolytic Activity in Germinating Sweet potato (Ipomoea batatasL.) Roots.' J. Amer. Soc. Hort. Sci. 119 (2): 313-20.

xiii. Ishiguro, Koji, Takahiro Noda, and Osamu Yamakawa. 2003. 'Effect of Cultivation Conditions on Retrogradation of Sweet potato Starch.' Starch/Stärke 55: 564-68.

xiv. Kays, Stanley J. 1998. 'Sweet potato.' Athens, GA.

xv. Kays, Stanley J. 2005a. 'Flavour - the Key to Sweet potato Consumption.' In 'Innovative Technologies for Commercialization' Consice Papers of the Second International Symposium on Sweet potato and Cassava, 179-80. Kuala Lumpur, Malaysia: Malaysian Agricultural Research and Development Institute (MARDI) Ministry of Agriculture and Agro-based Industries, Malaysia.

xvi. Kays, Stanley J. 2005b. 'Sweet potato Production Worldwide: Assessment, Trends and the Future.' In 1st International Symp. on Root and Tuber Crops; Acta Hort 670, ISHS, edited by M. A. Nichols, 19-25.

xvii. La Bonte, Don R, David H Picha, and Hester A Johnson. 2000. 'Carbohydrate-Related Changes in Sweet potato Storage Roots during Development.' J. Amer. Soc. Hort. Sci. 125 (2): 200-204.

xviii. Lewthwaite, S L, K H Sutton, and C M Triggs. 1997. 'Free Sugar Composition of Sweet potato Cultivars after Storage.' New Zealand Journal of Crop and Horticultural Science, 25 (June 1996): 33-41.

xix. Lin, R.-X., C.-S. Xie, Z.-X. Feng, and H.-C. Huang. 1995. 'A Study on Several Nutritional Compositions of Sweet Potato Germplasm in South China.' Scientia Agr. Sinica, no. 28: 39-45.

xx. Mcharo, M, and D. La Bonte. 2007. 'Genotypic Variation among Sweet potato Clones for SS-Carotene and Sugar Conten.' In 13th ISTRC Symposium, 746-54.

xxi. Mok, Il-Gin, D. E. Zhang, and E. E. Carey. 1997. 'Sweet Potato Breeding Strategy of CIP.' In Proceeding of the International Workshop on Sweet Potato Production System toward the 21st Century, edited by L. LaBonte et al., 9-27. Kyushu National Agricultural.

xxii. Nath, Rajib, C.K. Kundu, A. Majumder, SK. J. Islam, Sunil Gunri, A. Chattopadhyay, P. Bandopadhyay, and H. Sen. 2005. 'Promotion of Sweet potato in Alleviating Hunger and Nutritional Deficiencies in the Poverty Stricken and Environmentally Fragile Red and Laterite Ecosystem of West Bengal, India.' In 'Innovative Technologies for Commercialization' Consice Sapers of the Second International Symposium on Sweet potato and Cassava., 197-98.

xxiii. Noda, T., T. Kobayashi, and I. Suda. 2001. 'Effect of Soil Temperature on Starch Properties of Sweet Potatoes.' Carbohydrate Polymers 44: 239-46.

xxiv. Oduro, Vivian. 2013. 'Genetic Control of Sugars, Dry Matter and Beta-Carotene in Sweet potato (Ipomoea Batatas [L.] Lam).'PhD Thesis, University of Ghana, Legon. http://ugspace.ug.edu.gh.

xxv. Rees, D., Q. E. A. van Oirschot, R. Amour, E. Rwiza, R. Kapinga, and T. Carey. 2003. 'Cultivar Variation in Keeping Quality of Sweetpotatoes.' Postharvest Biology and Technology 28 (2): 313-25.

xxvi. Scott, G J, and L Maldonado. 1998. 'Sweet potato for the New Millennium: Trends in Production and Utilization in Developing Countries,' no. 39.

xxvii. Shih, Ming-chih, Ching-chuan Kuo, and Wenchang Chiang. 2009. 'Effects of Drying and Extrusion on Colour, Chemical Composition, Antioxidant Activities and Mitogenic Response of Spleen Lymphocytes of Sweet Potatoes.' Food Chemistry 117 (1). Elsevier Ltd: 114-21. doi: 10.1016/j.foodchem.2009.03.084.

xxviii. Teye, Ernest. 2010. 'Developing Appropriate Storage Technology for Sweet Potatoes (Ipomoea batatas Lam.) in the Coastal Savannah Zone of Ghana.'PhD Thesis, University of Cape Coast, Ghana.

xxix. Truong, Van-den, and Ramesh Y. Avula. 2010. 'Sweet Potato Purees and Powders for Functional Food Ingredients.' In Sweet Potato: Post-Harvest Aspects in Food, 117-61.

xxx. Walter, W.M., and G.L. Catignani. 1981. 'Biological Quality and Composition of Sweet potato Protein Fractions.' J. Agric. Food Chem 29: 797-99.

xxxi. Walter, William M., George L. Catignani, Leslie L. Yow, and David H. Porter. 1983. 'Protein Nutritional Value of Sweet Potato Flour.' Journal of Agricultural and Food Chemistry 31 (5). American Chemical Society: 947-49. doi:10.1021/jf00119a006.

xxxii. Wang, Shu-Jen, Mei-Hui Chen, Yeh Kai-Wun, and Chia-Yin Tsai. 2006. 'Changes in Carbohydrate Content and Gene Expression during Tuberous Root Development of Sweet potato.' J. Plant Biochemistry and Biotechnology 15: 2125.

xxxiii. WHFoods. 2011. 'The World's Healthiest Foods.' http://whfoods.org/eathealthy.php, June 22 2011).

xxxiv. Zhang, Zhitian, Christopher C. Wheatley, and Harold Corke. 2002. 'Biochemical Changes during Storage of Sweet Potato Roots Differing in Dry Matter Content. Jour. Postharvest Biology and Technology. 24 (3): 317-325. 